\title{
Centrosema pascuorum LEGUMINOSA ADAPTIF PADA LAHAN KERING BERIKLIM SANGAT KERING NTT: EFEKTIVITAS DAN KOMPETITIVITAS STRAIN MUTAN BPT01
}

\author{
N.D. Purwantari', Sajimin ${ }^{1}$, A. Fanindi ${ }^{1}$ dan J. Nulik ${ }^{2}$ \\ ${ }^{1}$ Balai Penelitian Ternak,P.O.Box 221, Bogor 16002 \\ ${ }^{2}$ Balai Pengkajian Teknologi Pertanian, NTT \\ Email: dias@indo.net.id
}

\begin{abstract}
ABSTRAK
Centrosema pascuorum cv. Cavalcade adalah leguminosa herba, yang telah terbukti tahan kering seperti iklim di Nusa Tenggara Timur dengan 9 bulan musim kering dan 3 bulan musim hujan, yang dapat menyediaakan hijauan berkualitas tinggi terutama dalam musim kemarau. Jenis tanaman ini mempunyai kemampuan menambat $\mathrm{N}_{2}$ atmosfer bila bersimbiose dengan bakteri tanah rhizobia. Tujuan penelitian adalah mengevaluasi strain Rhizobium dalam menambat $\mathrm{N}_{2}$ atmosfer yang dibudidayakan di lapang. Uji kompetitivitas dan efektivitas dari strain rhizobia dilakukan di stasiun Percobaan Balitnak, Bogor, dengan $\mathrm{pH}$ tanah 5,8; bahan organik rendah, kandungan $\mathrm{N}$ rendah. Jenis tanaman yang digunakan adalah Centrosema pascuorum. Sebagai strain peciri digunakan strain mutan pada antibiotik rifampisin $25 \mathrm{ppm}$. Perlakuan (1) inokulasi, (2) tanpa inokulasi, (3) tanpa inokulasi dengan penambahan pupuk $\mathrm{N}$, nitrogen urea dengan dosis $50 \mathrm{~kg} / \mathrm{ha}$. Pupuk dasar $100 \mathrm{~kg} \mathrm{TSP} / \mathrm{ha}, 100 \mathrm{~kg} \mathrm{KCl} / \mathrm{ha}$. Parameter yang diukur, kandungan nitrogen tanaman, produksi hijauan, nodulasi dan prosentase bintil akar yang diinfeksi oleh inokulan yang diberikan (bintil akar recovery). Rancangan percobaan menggunakan adalah Rancangan Acak kelompok dengan 8 ulangan. Hasil menunjukkan adanya peningkatan produksi hijauan, tanaman yang dinokulasi dengan strain mutan BPTo1. Produksi berat kering hijauan yang dinokulasi mencapai $963,94 \mathrm{~kg} / \mathrm{ha}$ dan berbeda nyata lebih tinggi dibanding tanpa inokulasi $(\mathrm{P}<0.05)$, sedang yang tidak diinokulasi berkisar $589.94-635.86,44$ $\mathrm{kg} / \mathrm{ha}$. Berat segar bintil akar yang diinokulasi dengan strain mutan BPTo1 adalah 19,93 g/4 tanaman, dengan jumlah bintil akar berwarna merah mencapai 63\% sedang tanaman yang tidak diinokulasi 2,30 g/4 tanaman dan bintil akar berwarna merah 48\%. Bintil akar recovery, dari jumlah bintil akar yang diuji 20,34\% berasal dari inokulan yang diberikan. Sedang tanaman yang tidak dinokulasi, tidak ada bintil akar mengandung strain mutan BPTo1. Kandungan protein kasar hijauan tanaman yang diinokulasi strain mutan BPTo1, 24,06\% sedang yang tidak diinokulasi 14,59\%.
\end{abstract}

Kata kunci: C. pascuorum, kompetitivitas, strain mutan, Rhizobium, Produksi .

\begin{abstract}
Centrosema pascuorum cv. Cavalcade is annual leguminous herb adapted on dryland, dry climate of NTT with 9 months dry season and 3 months rainy season. This species has ability to fix atmospheric $\mathrm{N}_{2}$ when symbiosis with soil bacteria rhizobia. The objective of this study was to evaluate strain of Rhizobium on fixing $\mathrm{N}_{2}$ in the field. Competitiveness and effectiveness of mutant strain BPTo1 was conducted in IRIAP research station, in Bogor, with soil pH tanah 5,8 low organic matter low N. Centrosema pascuorum cv. Cavalcade was used in this study. Mutant strain BPTo1 of $25 \mathrm{ppm}$ rifampicin was used as inoculant marker. Treatments were (1) inoculation (2) no inoculation, no added $\mathrm{N}$ (3) no inoculation, added $\mathrm{N}$ (urea, $50 \mathrm{~kg} /$ ha). Basal fertilizer were $100 \mathrm{~kg} \mathrm{TSP} / \mathrm{ha}, 100 \mathrm{~kg} \mathrm{KCl} / \mathrm{ha}$. Parameters measured were $\mathrm{N}$ total shoot, Shoot production, nodulation, percentage nodules infected by inoculants (inoculants recovery). Treatments was arranged in Randomized complete block design and replicated 8 times. Results shows that shoot production was increased when inoculated by mutant strain BPTo1. Dry shoot production inoculated mutant strain BPTo1 was $963.94 \mathrm{~kg} / \mathrm{ha}$ and it was significantly higher than uninoculated plant. While uninoculated plant produced dry shoot in a range of $589.94-635.86 \mathrm{~kg} / \mathrm{ha}$. Nodules weight of inoculated plant by mutant strain BPTo1 was $19.93 \mathrm{~g} / 4$ plants, with effective nodules $63 \%$ and nodules weight of uninoculated plants was $2.30 \mathrm{~g} / 4$ plants with effective bintil akars was $48 \%$. Nodules recovery shows that $20.34 \%$ of nodules from inoculated plants was infected by inoculant mutant strain BPTo1. While no nodules were infected by mutant strain BPTo1 from uninoculated plants. Crude protein content of inoculated plant was 24,06\% while uninoculated plant was $14,59 \%$.
\end{abstract}

Keywords: C. pascuorum, competitiveness, mutant strain, Rhizobium, Production 


\section{PENDAHULUAN}

Centrosema pascuorum adalah leguminosa herba, tanaman semusim, yang telah terbukti tahan kering seperti iklim di Nusa Tenggara Timur dengan 9 bulan musim kering dan 3 bulan musim hujan. $C$. pascuorum beradaptasi pada kondisi tanah yang luas, dari tanah berpasir sampai liat dan agak masam sampai basa yaitu pH 5-8,5 (Clements, 1992).

C. pascuorum is dapat dikombinasikan dengan rumput atau ditanam secara monokultur dalam untuk sistem Ley (McCown et al., 1985; 1986); Dalam fase Ley ini C. pascuorum dapat menyediakan $80-100 \mathrm{~kg}$ nitrogen/ha untuk sistem tersebut (Thiagalingam et al., 1997). Bila dibuat hay, merupakan pakan yang sangat tinggi nutrisi (Clements, 1992).

Jenis tanaman ini, seperti tanaman leguminosa pada umumnya, mempunyai kemampuan menambat $\mathrm{N}_{2}$ atmosfer bila bersimbiose dengan bakteri tanah rhizobia yang sesuai. Keberhasilan simbiose dipengaruhi faktor lingkungan (Lie, 1974) maupun faktor biologi (Pena Cabriales dan Alexander, 1983). Salah satu faktor biologi adalah keberadaan rhizobia yang cocok dengan tanaman leguminosa yang dibudidayakan maupun yang tumbuh liar. Penggunaan agen biologi untuk meningkatkan produksi pertanian, termasuk tanaman pakan ternak telah banyak dilaporkan, antara lain oleh Centrosema pubescens lebih spesifik dalam kebutuhan akan rhizobia (Purwantari, 1989). Berkenaan adanya perubahan lingkungan global yang sedang terjadi didunia saat ini, misalnya peningkatan konsentrasi $\mathrm{CO}_{2}$ di atmosfer, yang merupakan salah satu gas rumah kaca ternyata menstimulasi pertumbuhan dan penambatan $\mathrm{N}_{2}$ oleh leguminosa (Teyssonneyre et al., 2002) dan respon penambatan $\mathrm{N}_{2}$ terhadap bertambahnya $\mathrm{CO}_{2}$ tergantung dari spesies legume dan suplai $\mathrm{N}$ tanah (West et al., 2005).

Tujuan peneitian adalah untuk mengevaluasi strain Rhizobium dalam menambat $\mathrm{N}_{2}$ atmosfer.

\section{MATERI DAN METODE}

Seleksi bakteri Rhizobium dilakukan dengan metoda multistage screening, dimana skrening melalui beberapa tahapan sebelum direkomendasikan untuk pengguna. Uji efektivitas dan kompetitivitas Strain mutan BPTo1 untuk Centrosema pascuorum dilakukan di stasiun Percobaan Balai Penelitian Ternak Cicadas, Bogor. Tanah dilokasi penelitian mempunyai $\mathrm{pH}$ 5,8 dan kandungan bahan organik dan $\mathrm{N}$ rendah. Perlakuan (A) inokulasi, (B) tanpa inokulasi, Pupuk dasar $100 \mathrm{~kg}$ TSP/ha, $100 \mathrm{~kg} \mathrm{KCl} /$ ha. Sebagai strain peciri digunakan strain mutan pada antibiotik rifampisin $25 \mathrm{ppm}$. Parameter yang diukur adalah kandungan nitrogen tanaman, produksi hijauan, nodulasi (jumlah, berat bintil akar) dan prosentase bintil akar yang diinfeksi oleh inokulan yang diberikan. Rancangan percobaan yang akan diterapkan adalah Rancangan Acak kelompok dengan 8 ulangan.

\section{HASIL DAN PEMBAHASAN}

\section{Produksi hijauan Centrosema pascuorum cv. Cavalcade}

Produksi hijauan tanaman yang diinokulasi mencapai $963,94 \mathrm{~kg} / \mathrm{ha}$ lebih tinggi secara nyata disbanding tanaman tanpa inokulasi $(\mathrm{P}<0,05)$. Inokulasi dengan strain mutan BPTo1 telah meningkatkan produksi hijauan kering C. pascuorum cv. Cavalcade sebesar 51,60\% - 63,4\% (Tabel 1). Kondisi ini didukung oleh berat segar bintil akar, dimana perlakuan inokulasi membentuk bintil akar yang lebih berat yaitu 19,9340 g/4 tanaman dibanding tanpa inokulasi yang hanya 2,3037 g/4 tanaman dan proporsi warna merah jaringan bintil akar menunjukkan pola yang sama (Tabel 2). Tanaman yang tidak diinokulasi diinokulasi dan ditambah pupuk urea menghasilkan hijauan yang lebih rendah. Kemungkinan penambahan pupuk $\mathrm{N}$ anorganik 50 $\mathrm{kg} / \mathrm{ha}$ telah menghambat nodulasi dan penambatan $\mathrm{N}_{2}$ udara atmosfer seperti yang dilaporkan Dart dan Wildon (1970 bahwa pupuk anorganik N pada level sedang dan tinggi akan menurunkan nodulasi dan penambatan $\mathrm{N}$ dalam dalam asosiasi tanaman leguminosa - strain rhizobium. Nodulasi pada tanaman yang dipupuk dengan pupuk anorganik $\mathrm{N}$ membentuk bintil akar yang lebih sedikit (Tabel 2). Walaupun pemakaian pupuk anorganik pada fase pertumbuhan awal diperlukan untuk pertumbuhan tanaman sebelum bintil akar aktif menambat $\mathrm{N}_{2}$ atmosfer (Lie, 1974).

Tabel 1 Produksi Hijauan C. pascuorum cv. Cavalcadedi Tanah masam, Cicadas, Bogor

\begin{tabular}{lcc}
\hline \multicolumn{1}{c}{ Perlakuan } & $\begin{array}{c}\text { Produksi hijauan } \\
\text { kering }\left(\mathrm{kg} / 128 \mathrm{~m}^{2}\right)\end{array}$ & $\begin{array}{c}\text { Produksi hijauan } \\
\text { kering }(\mathrm{kg} / \mathrm{ha})\end{array}$ \\
\hline Strain mutan BPT01 & 12,3384 & $963,94^{\mathrm{a}}$ \\
Tanpa inokulasi, tanpa N & 7,5518 & $589,94^{\mathrm{b}}$ \\
Tanpa inokulasi, plus N & 8,1390 & $635,86^{\mathrm{b}}$ \\
\hline
\end{tabular}

\section{Nodulasi C. pascuorum cv. Cavalcade}

Jumlah bintil akar, berat bintil akar, lokasi bintil akar dan warna bintil akar merupakan indicator yang dapat digunakan untuk melihat respon inokulasi bakteri rhizobia secara kualitatif. Perlakuan inokulasi menghasilkan bintil akar yang paling tinggi berat segarnya dibanding tanpa inokulasi, dan proporsi bintil akar yang berwarna merah juga lebih banyak 
pada tanaman yang diinokulasi dibanding yang tidak dinokulasi (Tabel 2).

Tabel 2 Bintil akarasi pada C. pascuorum cv. Cavalcade di Tanah masam, Cicadas, Bogor

\begin{tabular}{lccc}
\hline \multicolumn{1}{c}{ Perlakuan } & $\begin{array}{c}\text { Berat segar } \\
\text { bintil akar } \\
\text { (g/4 tanaman) }\end{array}$ & Lokasi & Warna (\%) \\
\hline $\begin{array}{l}\text { Strain BPT01rifR } \\
\text { Tanpa inokulasi, }\end{array}$ & 2,934037 & lateral & 63 merah, 37 putih \\
$\begin{array}{l}\text { tanpa N } \\
\begin{array}{l}\text { Tanpa inokulasi, } \\
\text { plus N }\end{array}\end{array}$ & 3,3525 & lateral & 48 merah, 52 putih \\
\hline
\end{tabular}

Dari hasil pengamatan nodulasi terlihat bahwa tanah dilokasi sudah mengandung strain rhizobia untuk $C$. pascuorum. Jenis ini berdasarkan kebutuhan akan Rhizobium dikelompokkan dalam grup moderat (Purwantari et al., 2010), berbeda dengan $C$. pubescens yang lebih spesifik (Nurhayati et al., 1989).

\section{Analisa kimia hijauan C. pascuorum cv. Cav- alcade}

Strain mutan BPTo1 meningkatkan kandungan nitrogen pada hijauan C. pascuorum cv. Cavalcade, yang berarti meningkatkan kualitas hijauannya, terutama protein kasar (Tabel 3). Unsur Mo yang merupakan unsur yang sangat diperlukan oleh enzim nitrogenase dalam proses penambatan $\mathrm{N}_{2}$ mempunyai kandungan yang sama pada tanaman yang diinokulasi maupun yang tidak diinokulasi.

Tabel 3 Komposisi Kimia C. pascuorum cv. Cavalcade di Tanah masam, Cicadas, Bogor

\begin{tabular}{lccccc}
\hline \multicolumn{1}{c}{ Perlakuan } & $\begin{array}{c}\mathrm{N} \\
(\%)\end{array}$ & $\begin{array}{c}\mathrm{P} \\
(\%)\end{array}$ & $\begin{array}{c}\text { Ca } \\
(\mathrm{ppm})\end{array}$ & $\begin{array}{c}\text { Mo } \\
(\mathrm{ppm})\end{array}$ & $\begin{array}{c}\text { Zn } \\
(\mathrm{ppm})\end{array}$ \\
\hline Strain mutan BPT01 & 3,85 & 1,92 & 3,86 & 0,11 & 16,06 \\
Tanpa inokulasi, tanpa N & 2,08 & 2,53 & 1,33 & 0,11 & 7,37 \\
Tanpa inokulasi, plus N & 2,59 & 3,02 & 1,96 & 0,09 & 9,56 \\
\hline
\end{tabular}

Tabel 4. Recovery bintil akar C. pascuorum cv. Cavalcade, Cicadas 2011

\begin{tabular}{lcc}
\hline \multicolumn{1}{c}{ Treatment } & $\begin{array}{c}\text { number of bintil } \\
\text { akar yang diuji }\end{array}$ & BPT01 (\%) \\
\hline Strain mutan BPT01 & 59 & 20,34 \\
Uninoculated, no added N & 47 & 0 \\
Uninoculated, added N & 15 & 0
\end{tabular}

Penggunaan strain mutan adalah salah satu cara untuk mempelajari ekologi dari rhizobia (inokulan) yang diberikan pada tanaman leguminosa, selain dengan uji serologi (Vincent, 1970). Penggunaan mutan strain Rhizobium sebagai inokulan pada tanaman Sesbania sesban untuk mempelajari keberadaan inokulan setelah didalam tanah (Purwantari et al., 1998), dimana strain mutan tersebut dapat digunakan sebagai peciri.

Tanaman yang tidak dinokulasi menunjukkan tidak adaya bintil akar yang diinfeksi oleh inokulan yang digunakan strain mutan BPTo1. Sedang tanaman yang diinokulasi, bintil akar yang diinfeksi oleh inokulan hanya 20,34\% sehingga sisanya diinfeksi oleh Rhizobium alam (Tabel 4)

\section{SIMPULAN}

Inokulasi strain mutan BPTo1 pada Centropsema pascuorum meningkatkan produksi hijauannya Produksi yang tidak diinokulasi $589.94-635.86 \mathrm{~kg} /$ ha dan yang dinokulasi 963,94 kg/ha/ Kandungan nitrogen hijauan tanpa inokulasi dari 2,59\% dan tanaman yang diinokulasi $3,85 \%$.

\section{DAFTAR PUSTAKA}

Cameron, A.G. 2005. Centrosema pascuorum in Australia's Northern Territory: a tropical forage legume success story. p. 219. www.tropicalgrasslands.asn.au (3 May, 2013

Clements, R.J. 1992. Centrosema pascuorum Martius ex Benth. In: Mannetje, L. 't and Jones, R.M. (eds.). Plant Resources of South-East Asia, Vol. 4: Forages. Pudoc Scientific Publishers, Wageningen, Netherlands p.84-86.

Lie, T.A. 1974. Environmental effects on bintil akaration and symbiotic nitrogen fixation: The Biology of Nitrogen Fixation (Ed.) A. Quispel. North Holland Publishing Company. pp. 557-561

*Nurhayati, D.P., D.A. Ivory and W.W. Stur. 1989. the effectiveness and competitiveness of some Indonesian strains on tropical legumes grown in four soil types of Java. Plant and Soil 117: 146-150.

Pena-Gabriales J.J., and M. Alexander. 1983. Growth of Rhizobium in soil amended with organic matter. Soil. Sci. Soc.Am.J. 47:

Purwantari, N.D., D.A. Ivory and W.W. Stur. 1989. the effectiveness and competitiveness of some Indonesian strain. Plant and Soil 117: 146-150.

Purwantari, N.D., Sajimin, E. Sutedi. 2010. Efektivitas Strain Rhizobia pada Tanaman Pakan Ternak Terseleksi. Laporan Penelitian TA 2010. Balai Penelitian Ternak, Ciawi, Bogor

Purwantari, N.D. P.J. Dart, R.A. Date and M.B. Peoples. 1998. Response of Sesbania sesban to the inoculation of rifampicin mutant rhizobial strain of PMA295 grown in the field. Indon. J. Crop Sci. 13:1-6

Purwantari, N.D. 2000. Preliminary ecological study of $R h i-$ zobium: Selection of antibiotic resistant mutants of $R h i-$ zobium PMA295 bintil akarating Sesbania sesban. IJAS

Teyssonneyre, F., C. Picon-Cochard, R. Falcimagne and J.F. Soussana. 2002. Effects of elevated $\mathrm{CO}_{2}$ and cutting frequency on plant community structure in a temperate grassland. Global Change Biol. 8: 1034-1046

Thiagalingam, K. Zuill, D. and Price, T. 1997. A review of Centrosema pascuorum (Centurion) cvv. Cavalcade and Bundey as a pasture legume in the ley farming system studies in North West Australia. Proceeding, XVIII International Grassland Congress, WinnipegSaskatoon, Canada. Vol. 1: 10/43-44.

Vincent, J.M. 1970. A manual for Practical Study of the Root-bintil akar Bacteria. International Biological Programme, Blackwell Scientific Publications, Oxford

West, J.B., Janneke Hillerislambers, T.D. Lee, S.E. Hobbie and P.B. Reich. 2005. legume species identity and soil N supply determine symbiotic nitrogen-fixation responses to elevated atmospheric $\left(\mathrm{CO}_{2}\right)$. New Physiologist 167: $523-530$ 